\title{
Alternative Strut and Tie Model for Reinforced Concrete Deep Beams
}

\author{
Ahmed Faleh Al-Bayati \\ Civil Engineering Department \\ Al-Nahrain University, Baghdad, \\ IRAQ \\ ahmed_lbyt@hotmail.com
}

Received: 25- Sep.-2017

Revised: 16-Dec.-2017

Accepted: 18- Dec.-2017

\author{
http://doi.org/10.29194/NJES21010086
}

\begin{abstract}
This paper presents a simple strut and tie model to calculate the shear strength of reinforced concrete deep beams. The proposed model assumes that the shear strength is the algebraic sum of three strength components: concrete diagonal strut, vertical stirrups, and horizontal web reinforcements. The contribution of each strength components was calibrated with the test results of 305 deep beams compiled from previous studies with wide range of geometrical and material properties. The predictions of the proposed model were compared with those of the current codes of practice (ACI-318-14 and ASHTOO 2014) and those of existing model in the literature. Comparisons revealed that the proposed model provided better predictions than other models. The mean of predicted strength to test of the proposed model, the ACI-318-14 model, the ASHTOO 2014 model were 0.98, 0.79 , and 0.75 , respectively. The corresponding standard deviations were $0.17,0.28$, and 0.49 , respectively.
\end{abstract}

Keywords: Reinforced concrete, deep beams, shear strength, concrete efficiency factor, strut and tie model.

\section{Introduction}

Reinforced concrete deep beams are widely used in construction as load transferring structural members. They are short and deep with a relatively small shear span-effective depth ratio, (a/d), not exceeding 2.5[1]. For such geometric arrangements, their behavior is different from that of shallow beams. In which, the distribution of longitudinal strains is nonlinear and the concept of Bernoulli's beam theory of "plane section remain plane" is not valid due to shear distortions [1]. Deep beams are normally governed by shear instead of flexure in the existence of sufficient bending reinforcements, where the shear strength is higher than those developed by shallow beams [2].

Consequently, deep beams are designed against shear either by nonlinear analysis or strut and tie method, and the sectional approach adopted for shallow beams is not appropriate due to the differences illustrated earlier. In the strut and tie method, the applied loads are assumed to be resisted by diagonal compressive struts and tension ties joined together at nodes to form a truss, refer to Figure 1. This method is usually favored by design engineers owing to its simplicity [3, 4], and therefore, it has been adopted in the codes of practice [5-7] not only to design deep beams but also to design other discontinuities such as corbels and pile caps.

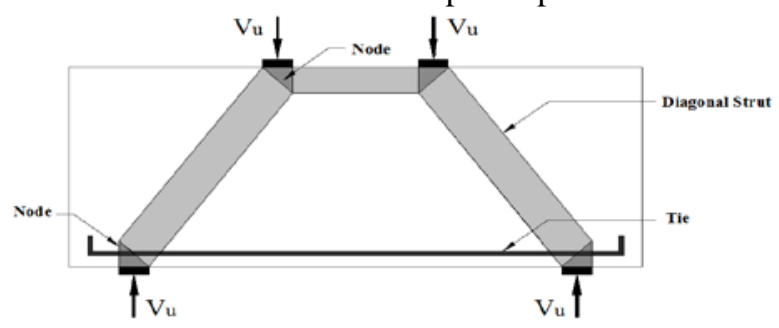

Figure 1: Strut and tie model

However, previous studies have indicated that the shear predictions of the current codes with regards to deep beams are usually conservative and widely scattered [4, 8-12]. Furthermore, designers found these models are difficult to apply due to the iterative procedure and the infinite shape and dimension for struts and ties, leading to various solutions [10, 13]. Although several non-iterative models [8-11] were proposed to improve the shear strength calculations, these models suffered from lacking of sufficient test database and ignored important test parameters. The use of deep beams in construction is difficult in the absence of a rational design model to calculate their shear strength. Therefore, there is a need to develop a simple design model that accurately predicts the shear strength.

In this paper, an alternative strut and tie model is proposed to calculate the shear strength of normal and high strength deep beams. The proposed model reflects the physical behavior of deep beams subjected to high concentrated loadings by taking into account the effects of governing parameters such as shear span-effective depth ratio, longitudinal and web reinforcement, and material strengths. 
Table 1: Details of deep beams without web reinforcements

\begin{tabular}{|c|c|c|c|c|c|c|}
\hline Reference & No. of beams & $d(\mathrm{~mm})$ & $a / d$ & $f_{c}(\mathrm{MPa})$ & $\rho_{l}(\%)$ & $\mathrm{f}_{y l}(\mathrm{MPa})$ \\
\hline Smith and Vantsiotis [14] & 5 & 305 & $0.77-2.01$ & $19.5-21.7$ & 1.94 & 422 \\
\hline Oh and Shin [15] & 5 & 500 & $0.5-2.0$ & $23.7-49.1$ & 1.56 & 483 \\
\hline Kani [16] & 35 & $269-1097$ & $0.98-2.03$ & $17.4-36.4$ & $0.83-2.77$ & $352-486$ \\
\hline De Cossio \& Seiss [17] & 2 & $252-254$ & 2.0 & $21.0-28.1$ & $0.98-3.36$ & $303-459$ \\
\hline Ahmad and Lu [18] & 11 & $184-208$ & $1.0-2.3$ & $60.8-67.0$ & $1.77-6.64$ & $483-586$ \\
\hline Yang et al. [19] & 16 & $215-935$ & $0.53-2.0$ & $31.5-94.9$ & $0.98-4.58$ & $500-804$ \\
\hline Moody et al. [20] & 11 & 533 & 1.52 & $17.2-25.0$ & $2.27-4.25$ & 483 \\
\hline Ferguson [21] & 3 & $181-184$ & 1.451 .93 & $24-27.2$ & $2.12-2.33$ & 483 \\
\hline Kim et al. [22] & 2 & 191 & $1.5-2.0$ & 30.1 & 1.65 & 461 \\
\hline De Pavia [23] & 6 & $203-305$ & $0.67-1.33$ & $19.9-35.2$ & $0.83-2.58$ & 483 \\
\hline Tan et al. [24] & 3 & 443 & $0.85-1.69$ & $77.6-79.9$ & 2.58 & 499 \\
\hline Ghannoum [25] & 16 & $190-889$ & 2.5 & $34.2-58.6$ & $1.2-2.0$ & $385-477$ \\
\hline Tanimura and Sato [26] & 8 & 400 & $0.5-2.5$ & $23.2-79.2$ & $0.42-2.14$ & $458-1330$ \\
\hline & Total No. 123 & & & & & 17.2 \\
\hline
\end{tabular}

Table 2: Details of deep beams with web reinforcements

\begin{tabular}{|c|c|c|c|c|c|c|c|c|c|c|}
\hline Reference & $\begin{array}{l}\text { No. of } \\
\text { beams }\end{array}$ & $d(\mathrm{~mm})$ & $a / d$ & $f_{c}(\mathrm{MPa})$ & $\begin{array}{c}\rho_{l} \\
(\%)\end{array}$ & $\begin{array}{c}\mathrm{f}_{y l} \\
(\mathrm{MPa})\end{array}$ & $\begin{array}{l}\rho_{v} \\
(\%)\end{array}$ & $\begin{array}{c}\mathrm{f}_{y v} \\
(\mathrm{MPa})\end{array}$ & $\begin{array}{c}\rho_{h} \\
(\%)\end{array}$ & $\begin{array}{c}\mathrm{f}_{y h} \\
(\mathrm{MPa})\end{array}$ \\
\hline $\begin{array}{c}\text { Smith and } \\
\text { Vantsiotis } \\
{[14]}\end{array}$ & 47 & 305 & $\begin{array}{l}1.0- \\
2.08\end{array}$ & $\begin{array}{c}16.1- \\
22.7\end{array}$ & 1.94 & 421.5 & $\begin{array}{c}0.18- \\
0.77\end{array}$ & 460 & $\begin{array}{c}0.23- \\
0.91\end{array}$ & 460 \\
\hline $\begin{array}{c}\text { Oh and } \\
\text { Shin [15] }\end{array}$ & 36 & 500 & $0.5-2.0$ & $\begin{array}{l}23.7- \\
73.6 \\
\end{array}$ & $\begin{array}{l}1.29- \\
1.56 \\
\end{array}$ & 483 & $\begin{array}{l}0.12- \\
0.37 \\
\end{array}$ & 414 & $\begin{array}{c}0.23- \\
0.94 \\
\end{array}$ & 414 \\
\hline $\begin{array}{c}\text { Aguilar et } \\
\text { al. [27] }\end{array}$ & 4 & $\begin{array}{l}791- \\
801\end{array}$ & $\begin{array}{l}1.14- \\
1.27 \\
\end{array}$ & $28-32$ & $\begin{array}{l}1.25- \\
1.40 \\
\end{array}$ & 483 & $\begin{array}{l}0.1- \\
0.31 \\
\end{array}$ & 414 & $\begin{array}{l}0.1- \\
0.35 \\
\end{array}$ & 414 \\
\hline $\begin{array}{c}\text { Tan et } \\
\text { al.[24] }\end{array}$ & 14 & 463 & $\begin{array}{c}0.27- \\
2.5 \\
\end{array}$ & $\begin{array}{l}41.1- \\
57.3 \\
\end{array}$ & 1.23 & 410 & 0.48 & 375.2 & - & - \\
\hline $\begin{array}{c}\text { Tanimura } \\
\text { and Sato } \\
{[26]}\end{array}$ & 36 & 400 & $0.5-2.5$ & $\begin{array}{l}21.4- \\
97.5\end{array}$ & $\begin{array}{l}0.42- \\
2.14\end{array}$ & $\begin{array}{l}458- \\
1330\end{array}$ & $\begin{array}{l}0.21- \\
0.95\end{array}$ & $\begin{array}{l}368- \\
1051\end{array}$ & - & - \\
\hline $\begin{array}{c}\text { Kong et al. } \\
\text { [28] }\end{array}$ & 9 & $\begin{array}{l}216- \\
724\end{array}$ & $\begin{array}{c}0.35- \\
1.18 \\
\end{array}$ & $\begin{array}{l}19.2- \\
24.6 \\
\end{array}$ & $\begin{array}{l}0.52- \\
1.73 \\
\end{array}$ & 289 & $\begin{array}{c}0- \\
2.45 \\
\end{array}$ & $\begin{array}{l}280- \\
303 \\
\end{array}$ & 0.86 & 303 \\
\hline \multirow[t]{6}{*}{ Clark [29] } & 36 & 390 & $\begin{array}{l}1.17- \\
2.34 \\
\end{array}$ & $\begin{array}{l}13.8- \\
44.7 \\
\end{array}$ & $\begin{array}{c}1.63- \\
3.1 \\
\end{array}$ & 335 & $\begin{array}{l}0.38- \\
1.22 \\
\end{array}$ & 331 & - & - \\
\hline & $\begin{array}{c}\text { Total } \\
\text { No. }=182\end{array}$ & & & & & & & & & \\
\hline & Min & 216 & 0.27 & 13.8 & 0.42 & 289 & 0 & 417.8 & 0 & 0 \\
\hline & Max & 801 & 2.5 & 97.5 & 3.1 & 1330 & 2.45 & 1051 & 0.94 & 460 \\
\hline & AVG & 409.9 & 1.2 & 32.8 & 1.8 & 454.5 & 0.5 & 134.3 & 0.2 & 263.6 \\
\hline & STDEV & 98.8 & 0.5 & 17.4 & 0.6 & 163.4 & 0.4 & 0.4 & 0.3 & 215.7 \\
\hline
\end{tabular}




\section{Test Database}

A total of 368 test data of simple span reinforced concrete deep beams subjected to concentrated loadings were compiled from previous studies [14-29] to develop the proposed model. These beams have wide range of test parameters. Various failure modes of reinforced concrete deep beams were observed from pervious experimental investigations including: shear associated with crushing or splitting of diagonal strut, yielding of flexural reinforcements, and bearing at the nodal zones $[2,8,9,10]$. Since the proposed model is concerned with shear calculations, only the test results of 305 deep beams that described to have failed in shear are included in the database and the rest were left out.

The database is divided into two subsets: deep beams without web reinforcements and deep beams with web reinforcements. A total of 123 deep beams without web reinforcements are used to determine the contribution of diagonal concrete strut and the rest (182 beams) are used to determine the contributions of vertical and horizontal web reinforcements. Details of each subsets of the database are presented in Tables 1 and 2.

\section{Mechanism of the Proposed Model}

Figure 2 shows a typical simple span deep beam subjected to two concentrated loads (Vu), where the latter are applied at a distance (a) from the center of a nearest support. The longitudinal reinforcements (flexural reinforcements) are placed at a distance (d) from the top fiber. The vertical reinforcements (closed stirrups) are placed at a horizontal spacing of Sv, and the horizontal reinforcements (web bars) are placed at a vertical spacing of Sh.

Although various types of diagonal struts were suggested to describe the load transfer mechanism in deep beams [8], the proposed model has adopted a statically determined compression strut to ease the calculations without losing the accuracy. That is, the applied load, $V_{u}$, is assumed to be carried by a diagonal strut force, $F_{\text {strut }}$, to the supports, see Figure 3 (a). Failure is assumed to occur when the strength of diagonal strut is exceeded. Following the equilibrium analysis, the relationship between the applied load and the diagonal strut force can be expressed as follows:

$$
F_{s t r}=\frac{V_{u}}{\sin \theta}
$$

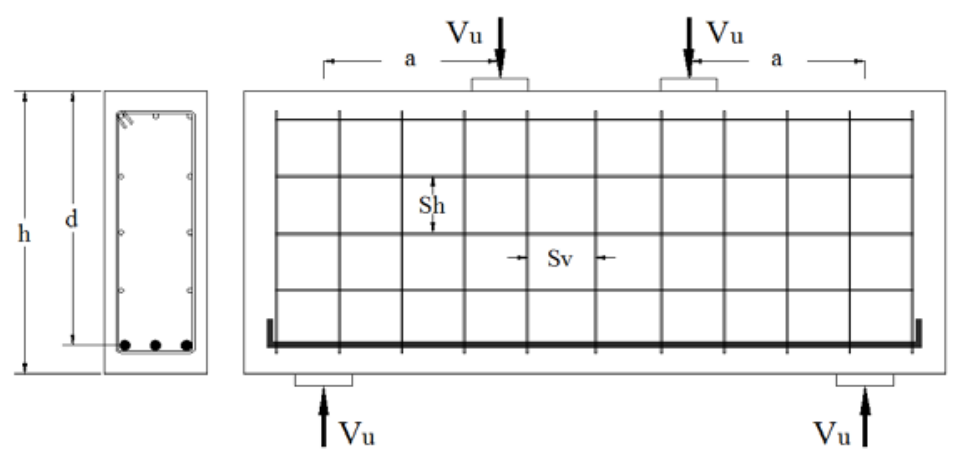

Figure 2: Reinforced concrete deep beam

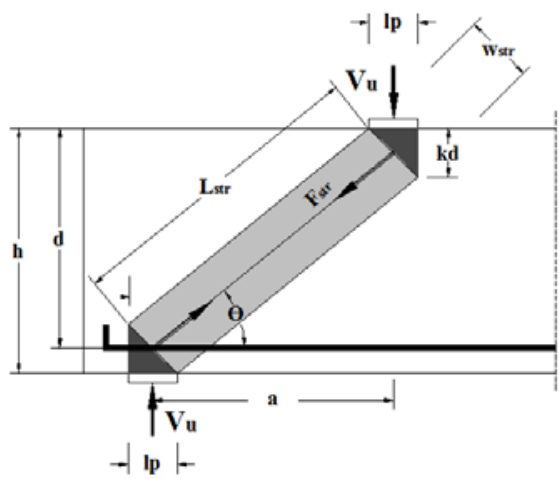

(a) Concrete diagonal strut

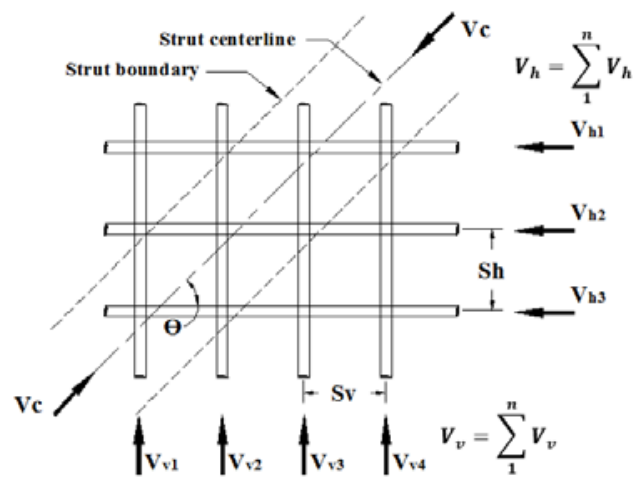

(b) Web reinforcements crossing the strut

Figure 3: Shear strength components 
The model further assumes that the strength of the diagonal strut, and hence, the shear strength of deep beam incorporates the contributions of three strength components: concrete compressive force of diagonal strut, and the equivalent forces of vertical stirrups and horizontal bars crossing the diagonal strut, $V_{v}$ and $V_{h}$, respectively (see Figure 3 (b)). Substituting these components into Eq. (1), the shear strength of deep beams is given:

$$
V_{\text {pred }}=F_{\text {str }} \sin \theta=V_{c} \sin \theta+V_{v}+V_{h} \tan \theta
$$

$\theta$, is the inclination angle of the diagonal strut:

$$
\theta=\tan ^{-1} \frac{j d}{a}
$$

Where, $a$, is the shear span measured from the center of applied load to the center of the support, $d$ is the effective depth of the beam , $j d=d-$ $k d / 3$ is the lever arm, and $k$ is obtained from the conventional bending theory of a singly reinforced concrete section [1]:

$$
k=\sqrt{\left(n \rho_{l}\right)^{2}+\left(2 n \rho_{l}\right)}-n \rho_{l}
$$

Where $n$ is the modular ratio, $n=E_{s t} / E_{C}, E_{s t}$ is the steel modulus of elasticity, $E_{s t}=$ $200000 \mathrm{MPa}$. [5], $E_{c}$ is the concrete modulus of elasticity, $E_{c}=4700 \sqrt{f_{c}{ }^{\prime}}$ [5], $f_{c}{ }^{\prime}$ is the cylinder concrete compressive strength, $\rho_{l}$ : longitudinal reinforcement ratio.

\section{Contribution of Concrete Compressive Strength, $V_{c}$}

In the absence of web reinforcements, the applied loads are resisted only by the concrete compressive diagonal struts developed between applied loads and supports, see Figure 3 (a). For deep beams having a sufficient flexural reinforcements, the shear strength is governed by the compressive strength of the diagonal strut. Previous tests on deep beams showed that the diagonal web cracks are propagated in an irregular shape [14, 15, 30, 31], and therefore, the concrete diagonal strut has been idealized in various forms [32]. This model adopts a prismatic one with a uniform width. Since the situation of deep beams is similar to that of double corbels in terms of loading conformance and failure modes $[33,34]$, and in order to reflect the behavior of deep beams failing in shear with sufficient flexural capacity, the width of diagonal strut suggested by Howang et al.[34] is adopted here:

$$
w_{s t r}=\sqrt{k d^{2}+l_{p}^{2}}
$$

Where $k$ is defined in Eq. (4), and $l_{p}$ is the width of a column or a bearing plate. By assuming the strut is subjected to an axial compressive stresses, the force provided by the diagonal strut can be computed from the product of the effective concrete strength, $f_{c e}$, and the strut area, $A_{s t r}$. The compressive force developed by the diagonal strut force of a deep beam with a rectangular cross-section can be determined from the following:

$$
V_{c}=f_{c e} A_{s t r}=v f_{c}{ }^{\prime} w_{s t r} b
$$

Where, $v$ is the concrete efficiency factor and $b$ is the width of a beam. Substituting Eq. (6) into Eq. (2), the shear strength of deep beams with no web reinforcement is given by:

$$
V_{\text {pred }}=V_{c} \sin \theta=V_{\text {str }} \sin \theta=
$$$$
f_{c e} A_{s t r} \sin \theta=v f_{c}{ }^{\prime} w_{s t r} b \sin \theta
$$

\section{Concrete Efficiency Factor}

In applying the strut and tie method to design reinforced concrete members, the use of efficiency factor is necessary to allow for the fact that the compressive strength provided by concrete diagonal strut is softer than that obtained from standard cylinder tests. This is attributed to the tensile strain developed parallel and normal to the axis of diagonal strut [2, 35].

Various efficiency factors were suggested earlier. These factors are varying from a single value [5-7] to more sophisticated expressions depending on concrete compressive strength [21, 36], strain condition [37, 38], the shear spaneffective depth ratio [8], or the combination of concrete compressive strength and the shear spaneffective depth ratio [11]. Chapter 14 in the current version of the ACI-318-14 [5] has adopted a single value efficiency factors ranging from 0.4 to 1.0, depending on the strut geometry, the presence of transverse reinforcements, and ignoring other important parameters. The ACI model has therefore been criticized to be an arbitrary with no unique solution, leading to conservative strength estimations [4, 12, 13].

To develop a reliable efficiency factor that reflects the actual behavior, reference is made to tests observations of deep beams with no web reinforcements to examine the effect of geometrical and material properties on the shear strength. It was observed that concrete strength, longitudinal reinforcement, and shear span to effective depth ratio $(\mathrm{a} / \mathrm{d})$ have pronounced effect on the shear strength of deep beams $[14,16,18$, 19]. To be precise, the shear strength was observed to decrease with the increase of concrete strength and shear span to effective depth ratio (a/d). Shear strength, however, was observed to increase with the increase of longitudinal reinforcement, $\rho_{l}$. To comply with the experimental observations, the proposed concrete efficiency factor is given by:

$v=c_{1}\left(\frac{c_{2}}{a / d}-c_{4}\right)\left(\frac{c_{5}}{{f_{c}}^{{ }^{c_{6}}}}\right)\left(\frac{\varnothing^{c_{7}}}{c_{8}}\right)$

Where, $c_{1}-c_{8}$ are empirical coefficients, $\emptyset$ is the mechanical properties of the section, $\varnothing=$ $\frac{f_{y} \rho_{l}}{f_{c}{ }^{\prime}}$, and $f_{y}$ is the yield strength of longitudinal reinforcements. 
The Empirical coefficients ( $c_{1}$ to $c_{8}$ ) are determined from nonlinear regression analysis conducted using SPSS statistics 22 [39]. They are calibrated with the tests results of 123 reinforced concrete deep beams with no web reinforcements, refer to Table 1.

The nonlinear regression analysis led to set of $c_{1}=1.6, \quad c_{2}=3.7, \quad c_{3}=0.25, \quad c_{4}=1.8, \quad c_{5}=$ $0.1, \quad c_{6}=0.3, \quad c_{7}=0.4, \quad$ and $\quad c_{8}=0.15$. Substituting these coefficients into Eq. (8), the concrete efficiency factor can be expressed as follows:

$$
\begin{gathered}
v=1.6\left(\frac{3.7}{a / d}-1.8\right)\left(\frac{0.1}{{f_{c}}^{0.3}}\right)\left(\frac{\emptyset^{0.4}}{0.15}\right)= \\
\frac{0.16 \emptyset^{0.4}}{0.15{f_{c}}^{0.3}}\left(\frac{3.7}{a / d}-1.8\right)
\end{gathered}
$$

\section{Contribution of Web Reinforcements, $V_{v}$ and $V_{h}$}

In addition to concrete contribution, the equivalent forces of vertical and horizontal reinforcements are important to be considered in the calculations of the shear strength. This is due to the fact that when the capacity of the concrete diagonal strut is reached, the excess of the applied load, $V_{u}$, is assumed to be resisted by the developed equivalent forces of web reinforcements, $\quad V_{v}+V_{h} \tan \theta=V_{u}-V_{c} \sin \theta$ $[8,10]$.

In evaluating the contribution of web reinforcements, reference is made to the experimental investigations where strain of vertical stirrups and horizontal bars are measured to indicate the effective vertical stirrups and horizontal bars in resisting the applied loads.

It was observed that vertical stirrups and horizontal bars develop their yield strength only at the center of the shear span, and the tensile stresses were observed to decrease towards the supports and loadings [8, 10, 27]. This indicates that the average tensile stresses developed by vertical stirrups and horizontal bars are below the yield strength. To accurately estimate the contribution of web reinforcements, empirical coefficients are introduced to be calibrated with the test results:

$$
\begin{aligned}
& V_{v}+V_{h} \tan \theta=w_{1}\left(\rho_{v} b L_{s t r} f_{y v}\right)^{w_{2}}+ \\
& w_{3}\left(\rho_{h} b L_{s t r} f_{y v} \tan \theta\right)^{w_{4}}
\end{aligned}
$$

Where, $w_{1}-w_{4}$ are empirical coefficients to be determined from previous test results, $\rho_{v}$ is the ratio of vertical stirrups, $\rho_{v}=\frac{A_{v}}{b S_{v}}, \rho_{h}$ is the ratio of horizontal bars, $\rho_{v}=\frac{A_{h}}{b s_{h}}, A_{v}$ and $A_{h}$ are the area of vertical and horizontal reinforcements, respectively. $S_{v}$ and $S_{h}$ are the spacing of vertical and horizontal reinforcements, respectively. $L_{s t r}$ is the length of the diagonal strut, $L_{s t r}=$ $\sqrt{(a)^{2}+j d^{2}}$.
The Empirical coefficients ( $w_{1}$ to $w_{4}$ ) are determined from nonlinear regression analysis conducted using SPSS statistics 22 [39]. These coefficients are calibrated with the test results of 182 tests results of reinforced concrete deep beams with web reinforcements, refer to Table 2 .

The nonlinear regression analysis led to set of $w_{1}=1.45, w_{2}=0.7, w_{3}=0.65$, and $w_{4}=0.4$. Substituting these values into Eq. (10), the contribution of web reinforcements can be expressed as follows:

$$
\begin{gathered}
V_{v}+V_{h} \tan \theta=1.45\left(\rho_{v} b L_{s t r} f_{y v}\right)^{0.7}+ \\
0.25\left(\rho_{h} b L_{s t r} f_{y v} \tan \theta\right)^{0.4}
\end{gathered}
$$

By substituting Eq. (7) and Eq. (11) into Eq. (2), the shear strength of a deep beam can be expressed as follows:

$$
\begin{aligned}
& V_{\text {pred }}=f_{\text {ce }} A_{\text {str }} \sin \theta+1.45\left(\rho_{v} L_{s t r} b f_{y v}\right)^{0.7}+ \\
& 0.25\left(\rho_{h} L_{s t r} b f_{y h} \tan \theta\right)^{0.4} \text { Eq. (12) }
\end{aligned}
$$

\section{Experimental verifications}

The proposed model and the existing models listed in Table 3 are evaluated by comparing their predictions with the test results of 305 deep beams compiled from previous studies. Furthermore, comparisons are made between predictions and test results in terms of controlling parameters: concrete compressive strength, shear span to effective depth ratio, (a/d), vertical stirrups, and horizontal bars, see Figures 5 to 8 . In which, the average of predicted strengths to tests is plotted versus each of the aforementioned parameter together with the perfect fit line to measure the trend of the predictions.

Figure 4 presents the comparisons between the test results of the 305 deep beams and the predicted shear strengths using the proposed model and each of the existing models summarized in Table 3, along with the average and the standard deviation of the predicted strength to test ratio. The mean of the predictions to tests of the proposed model, the ACI model [5] , the ASHTOO model [6], the Matamoros and Wong model [8], the Tang and Tan model [9], the Russo et al. model [10], and the Arabzadeh et al. model [11] were $0.98,0.82,0.76,0.98,0.95,1.34$, and 0.66, respectively. The corresponding standard deviations were $0.17,0.28,0.49,0.38$, $0.32,1.27$, and 0.33 , respectively. The small standard deviation of the proposed model clearly shows the significant enhancement in the accuracy of the predictions as compared with the existing models. It is important to note that, in the evaluation of the ACI model [5], 58 of the 305 beams used in the comparisons were eliminated because they did not satisfy the code limitations that requires the angle of inclination between the axis of concrete strut and the tie not to be smaller than 25 degrees. 
Table 3: Existing strut and tie models

\begin{tabular}{|c|c|}
\hline Model name & Strut and tie model \\
\hline ACI-318-14 [5] & $\begin{array}{c}V_{n}=f_{c e} b w_{s t r} \sin \theta, f_{c e}=0.85 \beta_{s} f_{c}, w_{s t r}=\min \left[\left(w_{t} \cos \theta+l_{p} \sin \theta\right),\left(h_{c} \cos \theta+l_{p} \sin \theta\right)\right] \\
\beta_{s}=1 \text { for prismatic shape, } \beta_{s}=0.75 \text { for bottle-shaped strut satisfying crack control } \\
\beta_{s}=0.6 \text { for bottle-shaped strut not satisfying crack control } \\
\text { Node compressive stress: } C C C: \beta_{n}=1.0, C C T: \beta_{n}=0.75, C T T: \beta_{n}=0.65 \\
w_{t}=2(h-d), h_{c} \text { is the depth of diagonal strut to be assumed, } \tan \theta=\frac{\left(h-0.5 w_{t}-0.5 h_{c}\right)}{a}\end{array}$ \\
\hline AASHTO LRFD [6] & $\begin{array}{c}V_{n}=f_{c u} b w_{s t r} \sin \theta, f_{c u}=f_{c} / 0.8+\epsilon_{1}, \epsilon_{1}=\epsilon_{1}+\left(\epsilon_{s}+0.002\right) / \tan \theta \\
w_{s t r}=\min \left[\left(w_{t} \cos \theta+l_{p} \sin \theta\right),\left(h_{c} \cos \theta+l_{p} \sin \theta\right)\right], w_{t}=2(h-d), h_{c} \text { is the depth of diagonal } \\
\text { strut to be assumed, Node compressive stress: } C C C=0.85 f_{c}, C C T=0.75 f_{c}, C T T=0.65 f_{c} \\
\tan \theta=\frac{\left(h-0.5 w_{t}-0.5 h_{c}\right)}{a}, \epsilon_{s} \text { tensile strain of the tension tie }\end{array}$ \\
\hline $\begin{array}{l}\text { Matamoros and } \\
\text { Wong [8] }\end{array}$ & $\begin{aligned} & V_{n}=0.35 / a / d \\
& w_{c} w_{s t r} b \sin \theta+A_{v} f_{y v}+3(1-a / d) A_{h} f_{y h}, \tan \theta=\frac{d}{a} \\
& w_{s t r}=w_{t} \cos \theta+l_{p} \sin \theta, w_{t}=2(h-d), A_{v}=\rho_{v} a b / 3, A_{h}=\rho_{h} a b / 3\end{aligned}$ \\
\hline Tang and Tan [9] & $\begin{array}{c}\frac{1}{V_{n}}=\frac{1}{V_{d c}}+\frac{1}{V_{d s}}, V_{d c}=f_{c} b w_{s t r} \sin \theta, w_{s t r}=w_{t} \cos \theta+l_{p} \sin \theta \\
w_{t}=2(h-d), V_{d c}=\frac{f_{c t} A_{c t}+f_{y v} A_{v} \cos \theta+f_{y h} A_{h} \sin \theta+2 f_{y} A_{s} \sin \theta}{2 \cos \theta} \\
f_{c t}=0.5 \sqrt{f_{c}}, \tan \theta=\frac{j d}{a}, k=\sqrt{\left(n \rho_{l}\right)^{2}+\left(2 n \rho_{l}\right)}-n \rho_{l}, j d=d-k d / 3\end{array}$ \\
\hline Russo et al. [10] & $\begin{array}{c}V_{n}=0.545\left(k X f_{c} \cos \theta+0.25 \rho_{h} f_{y h} \cot \theta+0.35 a / d \rho_{v} f_{y v}\right) b d \\
X=0.74\left(\frac{f_{c}}{105}\right)^{3}-1.28\left(\frac{f_{c}}{105}\right)^{2}+0.22\left(\frac{f_{c}}{105}\right)+0.87, \tan \theta=\frac{a}{0.9 d} k=\sqrt{\left(n \rho_{l}\right)^{2}+\left(2 n \rho_{l}\right)}-n \rho_{l}\end{array}$ \\
\hline Arabzadeh et al. [11] & $\begin{array}{c}V_{n}=\frac{f_{c}^{0.7}}{0.5+0.1\left(\frac{a}{d}\right)^{2}} f_{c} b w_{s t r} \sin \theta+0.09 \rho_{p}{ }^{-0.35} A_{w p} \cos \theta \\
\rho_{p}=\rho_{v} \sin ^{2} \theta+\rho_{h} \cos ^{2} \theta, A_{w p}=\rho_{p} b w_{s t r}, \tan \theta=\frac{j d}{a}, \\
w_{s t r}=\min \left[\left(w_{t} \cos \theta+l_{p} \sin \theta\right),\left(h_{c} \cos \theta+l_{p} \sin \theta\right)\right], k=\sqrt{\left(n \rho_{l}\right)^{2}+\left(2 n \rho_{l}\right)}-n \rho_{l}, j d=d- \\
k d / 3\end{array}$ \\
\hline
\end{tabular}

Figure 5 compares the performance of the proposed model and the existing models with respect to concrete compressive strength. Seventy three percent of these beams (219 of 305) were cast from normal concrete with compressive strength below $45 \mathrm{MPa}$. It can be inferred from this figure that the proposed model performed consistently with the concrete compressive strength below $60 \mathrm{MPa}$ and slightly conservative with concrete strength above $60 \mathrm{MPa}$. The performance of other existing models

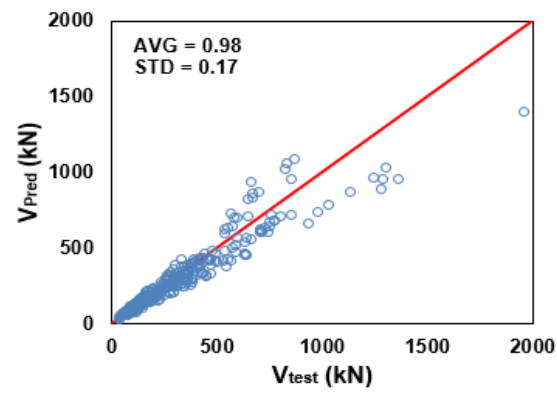

(a) Proposed model was inconsistent with the concrete compressive strength. To be specific, the ACI [5], the ASHTOO [6], and the Matamoros and Wong models [8] underestimated the shear strength of normal concrete beams and overestimated the shear strengths of high strength beams. The model of Russo et al. [10] slightly underestimated the shear strength of normal strength beams and overestimated of high strength concrete beams. The model of Arabzadeh et al. [11] was conservative and that of Tang and Tan [9] was scattered and unsafe.

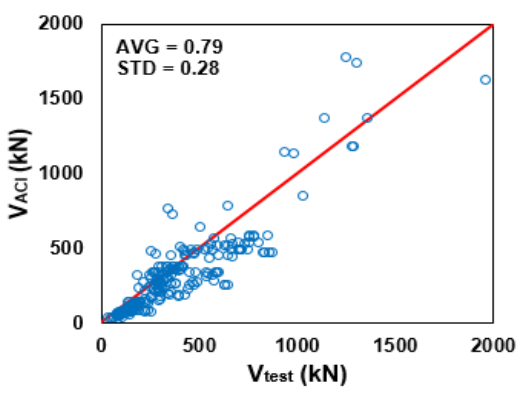

(b) ACI-318-14 [5] 


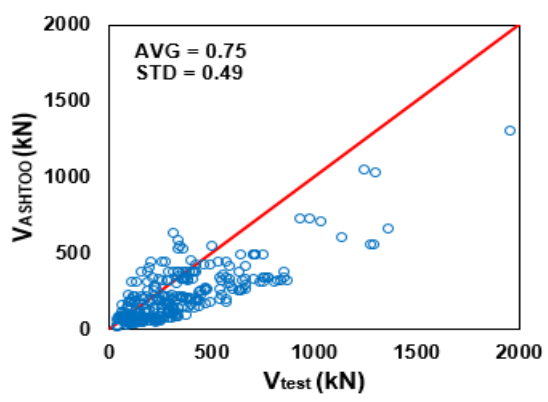

(c) AASHTO LRFD [6]

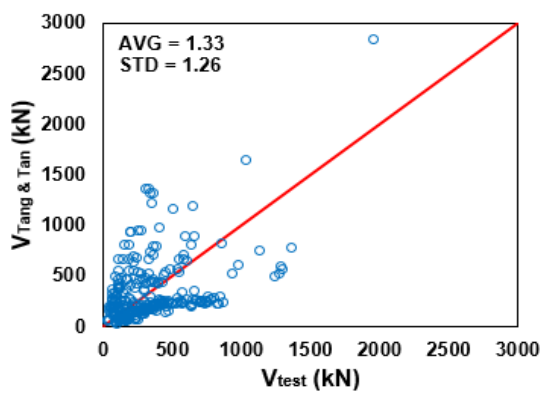

(e) Tang and Tan [9]

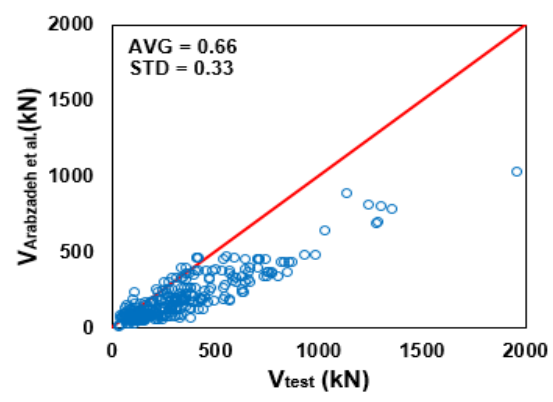

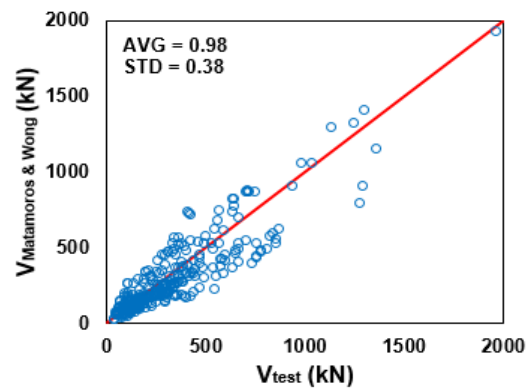

(d) Matamoros and Wong [8]

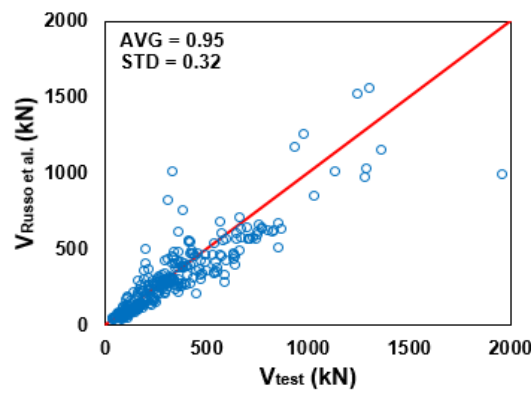

(f) Russo et al. [10]

(g) Arabzadeh et al. [11]

Figure 4: Comparisons between the shear strength predictions of the proposed model and the existing models

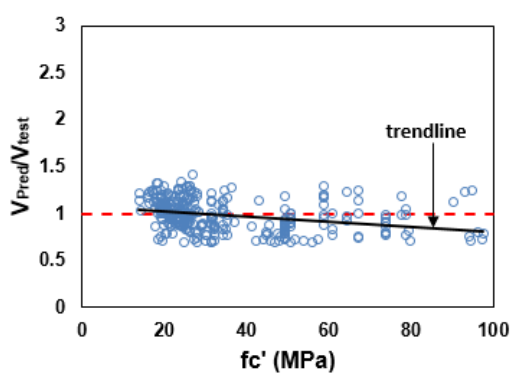

(a) Proposed model

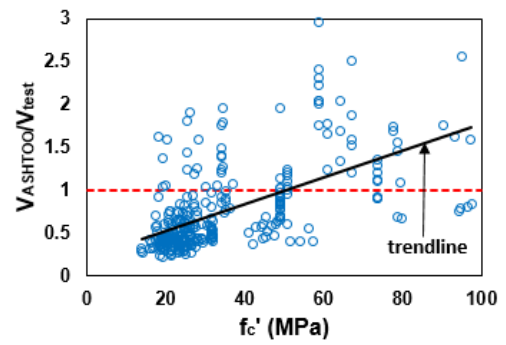

(c) AASHTO LRFD [6]

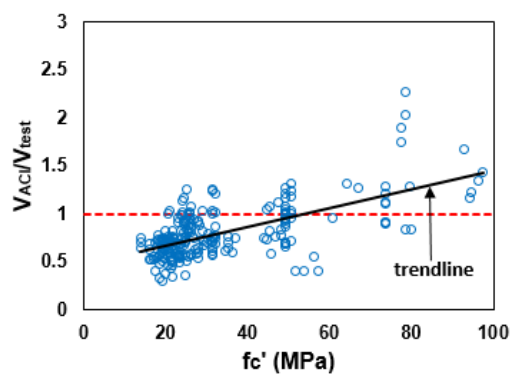

(b) ACI-318-14 [5]

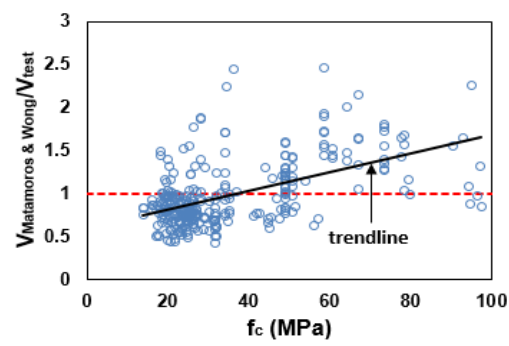

(d) Matamoros and Wong [8] 


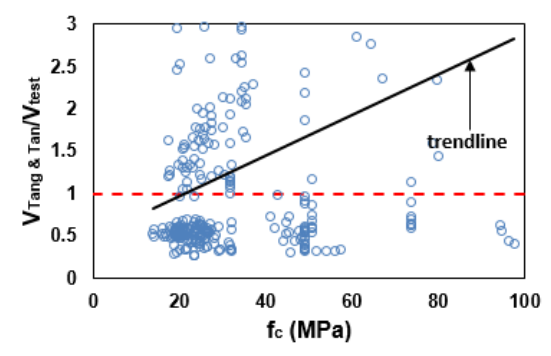

(e) Tang and Tan [9]

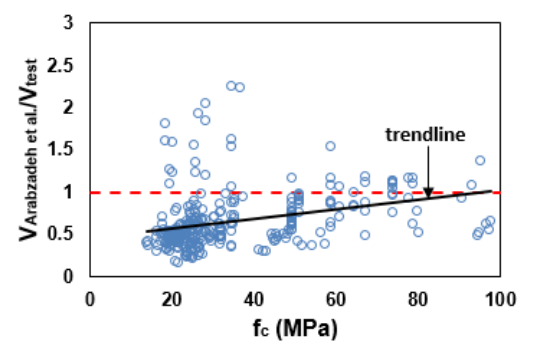

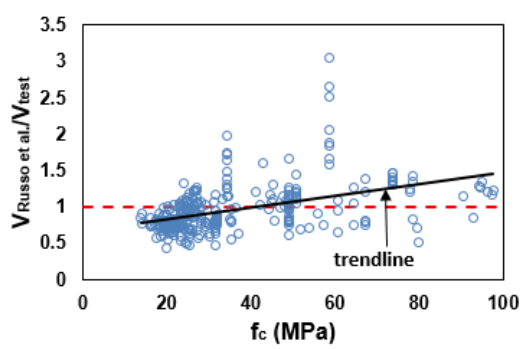

(f) Russo et al. [10]

(g) Arabzadeh et al. [11]

Figure 5: Comparisons between the shear strength predictions of the proposed model and the existing models with respects to concrete strength

Figure 6 compares the performance of the proposed model and the existing models with respects to the shear span to effective depth ratio, (a/d). Sixty percent the beams used in this study (182 of 305) were tested with $(\mathrm{a} / \mathrm{d})$ below 1.5 . Figure 6 indicates that, unlike the existing models, the performance of the proposed model was very consistent with $(\mathrm{a} / \mathrm{d})$. The ACI model [5] and that of Arabzadeh et al. [11] were conservative. Those of Matamoros and Wong [8] and Russo et al. [10] underestimated the shear strength of beams tested with $(\mathrm{a} / \mathrm{d})$ below 1.5 and overestimated the shear strengths of those tested with $(\mathrm{a} / \mathrm{d})$ above 1.5 . The performance of Tang and Tan's model [9] was scattered and unsafe.

Figure 7 compares the performance of the proposed model and the existing models with respect to the presence of vertical stirrups. It is worth mentioning that only beams reinforced with vertical stirrups were included, which sixty five percent of them (119 of 182) had vertical reinforcement ratio below $0.5 \%$. As can be seen that, the proposed model performed consistently with beams having a vertical reinforcement ratio below $1 \%$ and slightly overestimated those with vertical reinforcement ratio above $1 \%$. Whereas, all the existing models underestimated the shear strength of deep beams reinforced with vertical stirrups.

Figure 8 compares the performance of the proposed model and the existing models with respect to the presence of horizontal web bars. This figure only includes test beams with horizontal web bars, where seventy percent of them (60 of 86) had horizontal reinforcement ratio below $0.5 \%$. It can inferred from Figure 8 that only the proposed model and that of Matamoros and Wong [8] provided consistent predictions, while, the rest were conservative. 


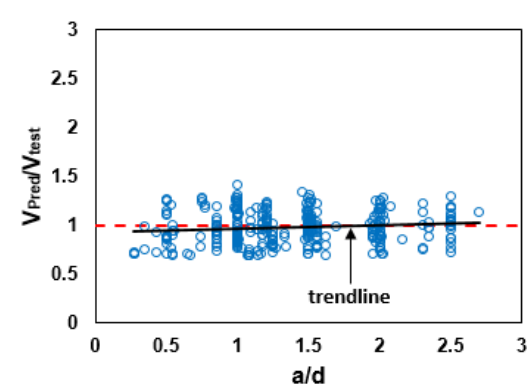

(a) Proposed model

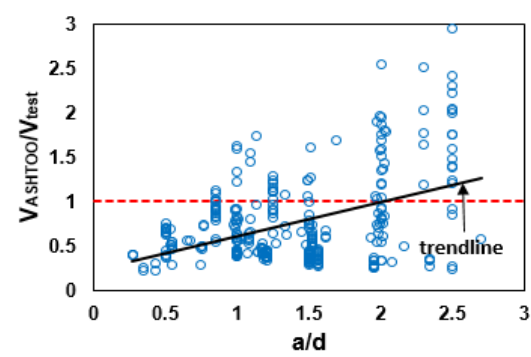

(c) AASHTO LRFD [6]

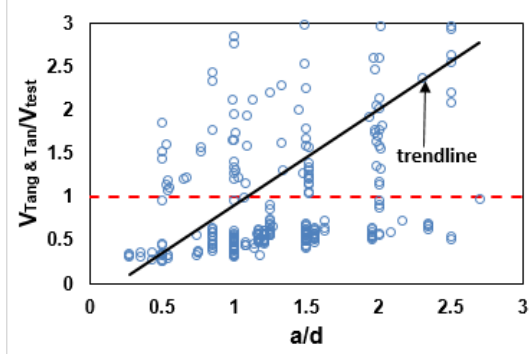

(e) Tang and Tan [9]

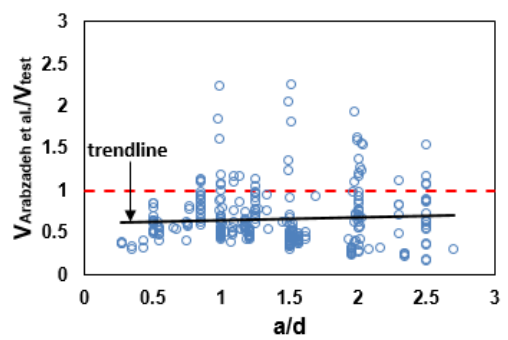

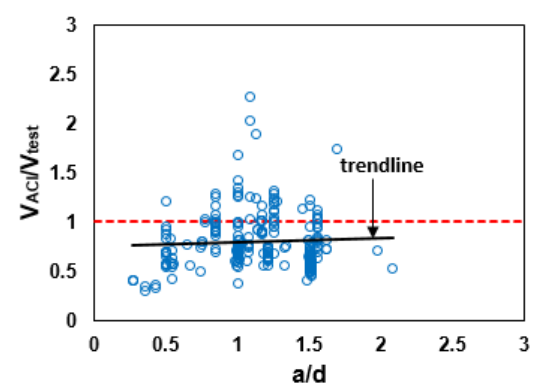

(b) ACI-318-14 [5]

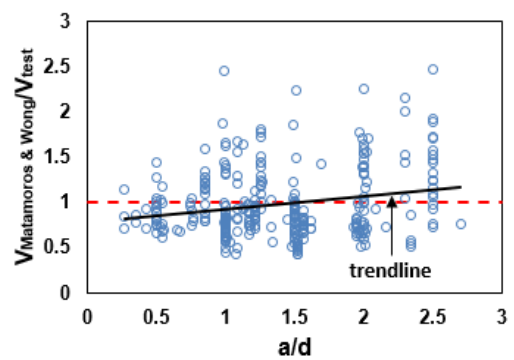

(d) Matamoros and Wong [8]

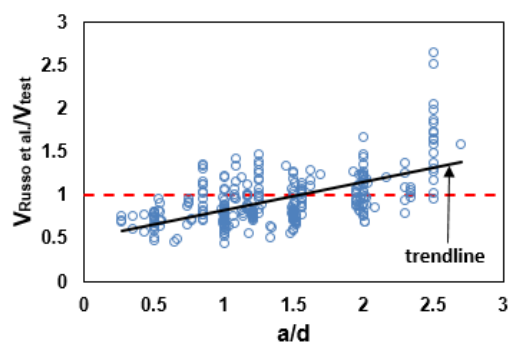

(f) Russo et al. [10]

(g) Arabzadeh et al. [11]

Figure 6: Comparisons between the shear strength predictions and of proposed model and the existing models with respects to shear span-effective depth ratio

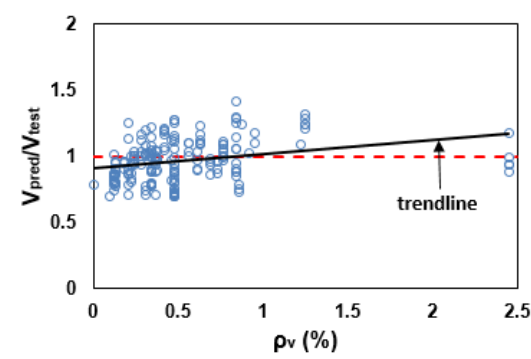

(a) Proposed model

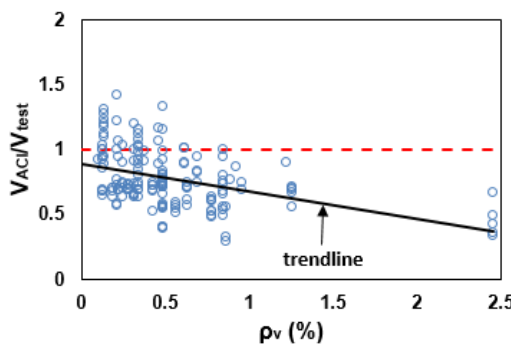

(b) ACI-318-14 [5] 


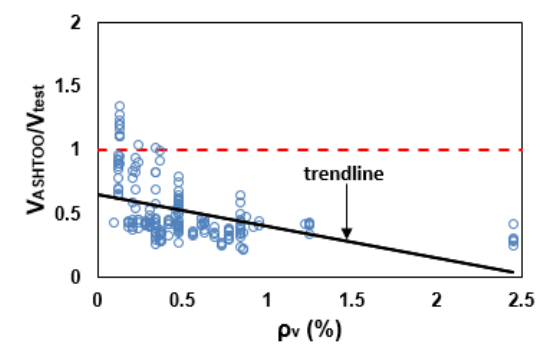

(c) AASHTO LRFD [6]

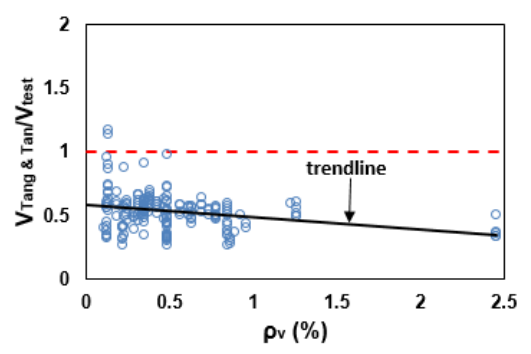

(e) Tang and Tan [9]

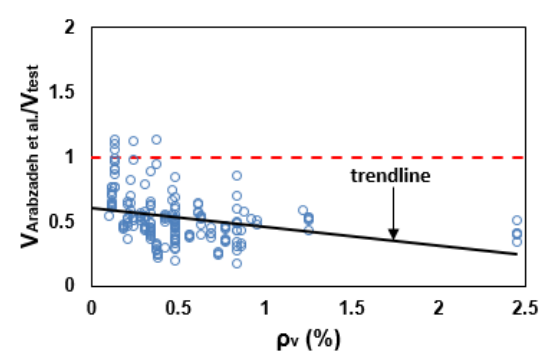

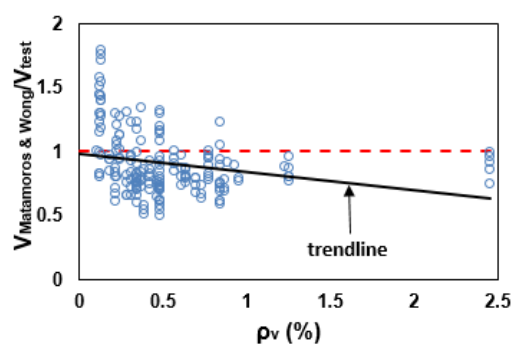

(d) Matamoros and Wong [8]

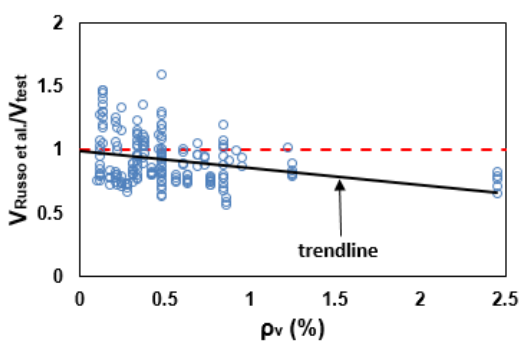

(f) Russo et al. [10]

(g) Arabzadeh et al. [11]

Figure 7: Comparisons between the shear strength predictions of the proposed model and the existing models with respects to vertical stirrups

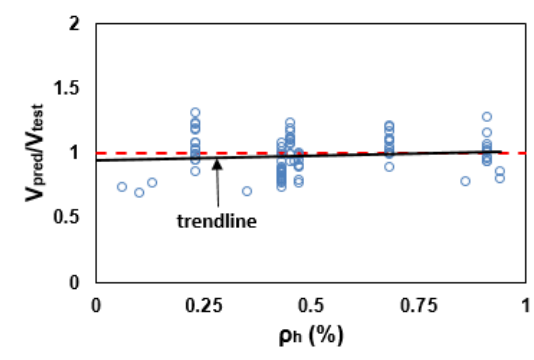

(a) Proposed model

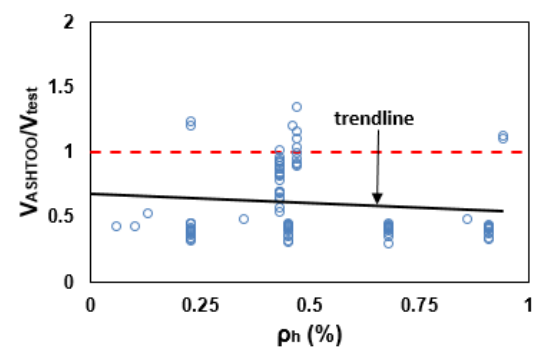

(c) AASHTO LRFD [6]

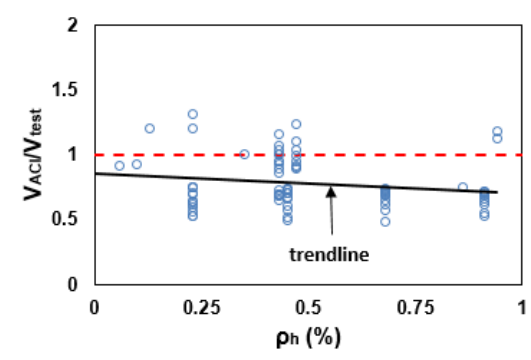

(b) ACI-318-14 [5]

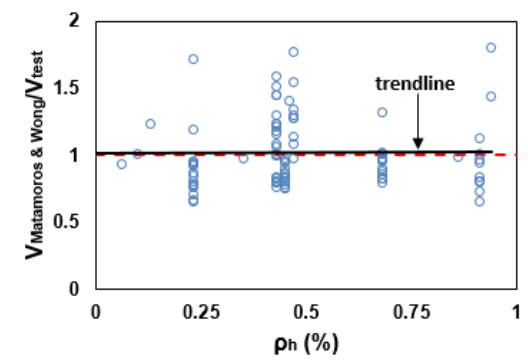

(d) Matamoros and Wong [8] 


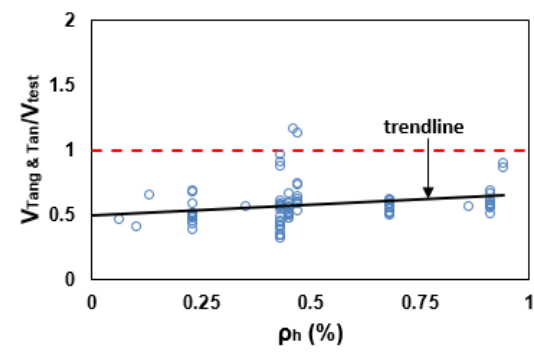

(e) Tang and Tan [9]

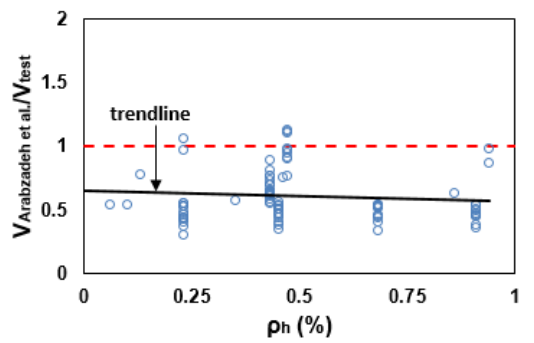

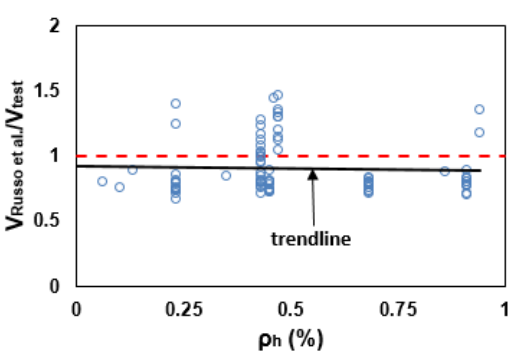

(f) Russo et al. [10]

(g) Arabzadeh et al. [11]

Figure 8: Comparisons between the shear strength predictions of the proposed model and the existing models with respects to horizontal bars

\section{Conclusions}

1. A simple strut and tie model is proposed to calculate the shear strength of deep beams. The model assumed that the shear strength is equal to the algebraic sum of the contribution of three strength components: concrete compressive force of diagonal strut and the equivalent forces of vertical and horizontal reinforcements crossing the diagonal strut.

2. The proposed load transfer mechanism associated with the proposed concrete efficiency factor and the proposed correction factors of web reinforcements have correlated favorably with the test results of 305 deep beams reported in the literature.

3. The predictions of the proposed model was compared with those of the current codes of practice, ACI-318-14 [5] and ASHTOO 2014 [6]. The comparisons showed that the proposed model achieved better agreement with the test results than these codes. The mean of predicted strength to test of the proposed model, the ACI-318-14, and the ASHTOO 2014 were 0.98, 0.79, and 0.75 , respectively. The corresponding standard deviations were $0.17,0.28$, and 0.49 , respectively.

4. The enhancements of the proposed model over those available in the current codes of practice (ACI and ASHTOO) is the combination of simplicity and consistency.
5. The predictions of the existing strut and tie models (Matamoros and Wong [8], Tang and Tan [9], Russo et al. [10], Arabzadeh et al. [11]) were compared with the results of 305 deep beams from previously experimental studies. Comparisons indicated that the models of Matamoros and Wong [8], Russo et al. [10], and Arabzadeh et al. [11] were conservative. Whereas, the model of Tang and Tan was unsafe.

\section{Notation}

\begin{tabular}{|l|l|}
\hline$a$ & Shear span. \\
\hline$A_{h}$ & Area of horizontal reinforcement. \\
\hline$A_{s r t}$ & Area of the diagonal strut. \\
\hline$A_{v}$ & Area of vertical reinforcement. \\
\hline$b$ & Width of a beam. \\
\hline$d$ & Effective depth of a beam. \\
\hline$a / d$ & Shear span to effective depth ratio. \\
\hline$E_{c}$ & Modulus of elasticity for concrete. \\
\hline$E_{s t}$ & Modulus of elasticity for steel. \\
\hline$f_{c}$ & Cylinder concrete compressive strength. \\
\hline$f_{c e}$ & Effective concrete strength. \\
\hline$F_{s t r}$ & Force of the diagonal strut. \\
\hline$f_{y}$ & Yield strength of steel reinforcements. \\
\hline$h$ & Total depth of a beam. \\
\hline$j d$ & Lever arm. \\
\hline$k$ & $\begin{array}{l}\text { Derived from the bending theory of a } \\
\text { singly reinforced beam.[1] }\end{array}$ \\
\hline$l_{p}$ & Width of the diagonal strut. \\
\hline$l_{s t r}$ & Length of the diagonal strut. \\
\hline$n$ & Modular ratio. \\
\hline$\rho_{l}$ & Flexural reinforcement ratio. \\
\hline$\rho_{h}$ & Horizontal reinforcement ratio. \\
\hline$\rho_{v}$ & Vertical reinforcement ratio. \\
\hline & \\
\hline
\end{tabular}




\begin{tabular}{|l|l|}
\hline$S_{h}$ & Spacing of horizontal reinforcements. \\
\hline$S_{v}$ & Spacing of vertical reinforcements. \\
\hline$v$ & Concrete efficiency factor. \\
\hline$V_{c}$ & Concrete compressive force. \\
\hline$V_{h}$ & $\begin{array}{l}\text { Equivalent force of horizontal } \\
\text { reinforcements. }\end{array}$ \\
\hline$V_{v}$ & $\begin{array}{l}\text { Equivalent force of vertical } \\
\text { reinforcements. }\end{array}$ \\
\hline$V_{\text {pred }}$ & Predicated shear strength. \\
\hline$V_{\text {test }}$ & Test shear strength. \\
\hline$w_{\text {str }}$ & Width of the diagonal strut. \\
\hline
\end{tabular}

\section{References}

[1] Wight, JK, "Reinforced Concrete: Mechanics and Design”, Global Edition, Pearson Education Limited 2016.

[2] Foster SJ, Malik AR, "Evaluation of efficiency factor models used in strut-and-tie modeling of nonflexural members", ASCE Journal of Structural Engineering, 2002 May, Vol. 128, No. 5, pp. 569-577.

[3] Zhong JT, Wang L, Deng P, Zhou M. “A new evaluation procedure for the strut-and-tie models of the disturbed regions of reinforced concrete structures”, Engineering Structures, 2017 Oct, Vol. 148, pp. 660-72.

[4] Tuchscherer RG, Birrcher DB, Williams CS, Deschenes DJ, and Bayrak O, "Evaluation of existing strut-and-tie methods and recommended improvements”, ACI Structural Journal. 2014 Nov 1, Vol. 111, No. 6, pp.1451-1460.

[5] ACI Committee 318, "Building Code Requirements for Structural Concrete (ACI 318 14)”, Commentary on Building Code Requirements for Structural Concrete (ACI 318M-14), American Concrete Institute, 2014.

[6] AASHTO, "AASHTO LRFD Bridge Design Specifications", American Association of State Highway and Transportation Officials, 2014.

[7] CSA Committee A23.3, "Design of Concrete Structures: Structures (Design)-A National Standard of Canada”, Canadian Standards Association, 2004.

[8] Matamoros, Adolfo B., and Kuok Hong Wong. "Design of simply supported deep beams using strut-and-tie models”, 2003 Nov., Vol. 100, No. 6, pp. 704-712.

[9] Tang CY, Tan KH, "Interactive mechanical model for shear strength of deep beams”, ASCE Journal of Structural Engineering, 2004 Oct, Vol. 130, No. 10, pp. 1534-44.

[10] Russo G, Venir R, Pauletta M, "Reinforced concrete deep beams-shear strength model and design formula”, ACI Structural Journal. 2005 May, Vol. 102, No. 3, pp. 429-37.

[11] Arabzadeh A, Rahaie AR, Aghayari R, “A simple strut-and-tie model for prediction of ultimate shear strength of RC deep beams",
International Journal of Civil Engineering, 2009 Sep, Vol. 7, No. 3, pp. 141-53.

[12] Kassem W. "Shear strength of deep beams: a mathematical model and design formula", Structural Concrete, 2015 Jun, Vo. 16, 2. pp. 18494.

[13] Park JW, Kuchma D, "Strut-and-tie model analysis for strength prediction of deep beams", ACI Structural Journal, 2007 Nov., Vol. 104, No. 6, pp. 657-660.

[14] Smith KN, Vantsiotis AS, "Shear strength of deep beams”, ACI Journal Proceedings 1982 May 1 Vol. 79, No. 3, pp. 201-213.

[15] Oh JK, Shin SW, "Shear strength of reinforced high-strength concrete deep beams", ACI Structural Journal, 2001 Mar, Vol. 98, No. 2, pp. 164-173.

[16] Kani G, "How safe are our large reinforced concrete beams?”, In ACI Journal Proceedings 1967 Mar, Vol. 64, No. 3, pp. 128-141.

[17] De Cossio RD, Siess CP, "Behavior and strength in shear of beams and frames without web reinforcement", ACI Journal Proceedings 1960 Feb, Vol. 56, No. 2, pp. 695-736.

[18] Ahmad SH, Lue DM, "Flexure-shear interaction of reinforced high strength concrete beams”, ACI Structural Journal, 1987 Jul, Vol. 84, No. 4, pp. 330-341.

[19] Yang KH, Chung HS, Lee ET, Eun HC, "Shear characteristics of high-strength concrete deep beams without shear reinforcements", Engineering Structures, 2003 Aug, Vol. 25, No. 10, pp.1343-1352.

[20] Moody KG, Viest IM, Elstner RC, Hognestad E, "Shear strength of reinforced concrete beams Part 1-Tests of simple beams", ACI Journal Proceedings 1954 Dec, Vol. 51, No. 12, pp. 317-332.

[21] Ferguson PM, "Some implications of recent diagonal tension tests”, ACI Journal Proceedings 1956 Aug, Vol. 53, No. 8, pp. 157-172.

[22] Kim D, Kim W, White RN, “Arch action in reinforced concrete beams-A rational prediction of shear strength”, ACI Structural Journal, 1999 Jul, Vol. 96, No. 4, pp. 586-593.

[23] De Paiva HA, Siess CP, "Strength and behavior of deep beams in shear", ASCE Structural Engineering Journal, 1965 Oct, Vol. 91, No. 5, pp.19-41.

[24] Tan KH, Kong FK, Teng S, Guan L, "Highstrength concrete deep beams with effective span and shear span variations", ACI Structural Journal, 1995 Jul, Vol. 92, No. 4, pp. 395-405.

[25] Ghannoum, W.M., "Size effect on Shear Strength of Reinforced Concree Beams,” M.Eng. Thesis, Department of Civil Engineering and Applied Mechanics, McGill University, 1998, 115 pp. 
[26] Tanimura Y, Sato T, "Evaluation of shear strength of deep beams with stirrups”, Quarterly Report of RTRI, 2005, Vol. 46, No. 1, pp. 53-58. [27] Aguilar G, Matamoros AB, ParraMontesinos GJ, Ramírez JA, Wight JK, "Experimental Evaluation of Design Procedures for Shear Strength of Deep Reinforced Concrete Beams”, ACI Structural Journal, 2002 Jan, Vol. 99, No. 4, pp. 539-548.

[28] Kong FK, Robins PJ, Cole DF, "Web reinforcement effects on deep beams", ACI Journal Proceedings 1970 Dec, Vol. 67, No. 12, pp. 1010-1018.

[29] Clark AP, "Diagonal tension in reinforced concrete beams”, ACI Journal Proceedings 1951 Oct, Vol. 48, No. 10, pp. 145-156.

[30] Shin SW, Lee KS, Moon JI, Ghosh SK, "Shear strength of reinforced high-strength concrete beams with shear span-to-depth ratios between 1.5 and 2.5”, ACI Structural Journal, 1999 Jul., Vol. 96, No. 4, pp. 549-556.

[31] Lu WY, Lin J, Yu HW, "Shear strength of reinforced concrete deep beams”, ACI Structural Journal. 2013 Jul, Vol. 110, No. 4, pp. 671-680.

[32] Brown MD, Bayrak O, "Minimum transverse reinforcement for bottle-shaped struts", ACI Structural Journal, 2006 Nov, Vol. 103, No. 6, pp. 813-821.
[33] Hwang SJ, Lu WY, Lee HJ, "Shear strength prediction for reinforced concrete corbels”, ACI Structural Journal, 2000 Jul, Vol. 197, No. 4, pp. 543-52.

[34] Hwang SJ, Lee HJ, “Strength prediction for discontinuity regions by softened strut-and-tie model”, ASC Journal of Structural Engineering, 2002 Dec, Vol. 128, No. 12, pp.1519-1526.

[35] Quintero-Febres CG, Parra-Montesinos G, Wight JK, "Strength of struts in deep concrete members designed using strut-and-tie method", ACI Structural Journal. 2006 Jul., Vol. 103, No. 4, pp. 577-586.

[36] Nielsen MP, Hoang LC, "Limit analysis and concrete plasticity”, CRC press, 2016.

[37] Vecchio FJ, Collins MP, "The modified compression-field theory for reinforced concrete elements subjected to shear”, ACI Journal Proceedings, 1986 Mar, Vol. 83, No. 2, pp. 219231.

[38] Vecchio FJ, Collins MP, “Compression response of cracked reinforced concrete”, ASCE Journal of structural engineering, 1993 Dec, Vol. 119, No. 12, pp. 3590-610.

[39] IBM SPSS Statistics 22, "SPSS Statistics 22 Manual”, Version 22, 2016.

\section{نموذج دعامة ورباط بديل للعتبات الخرسانية العميقة}

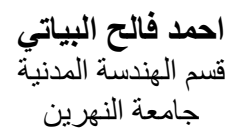

\footnotetext{
الخلاصة

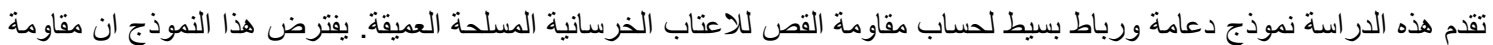

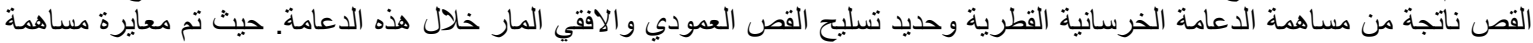

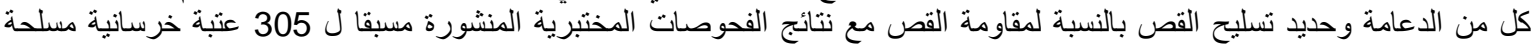

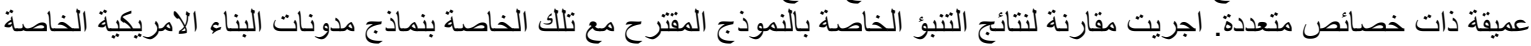

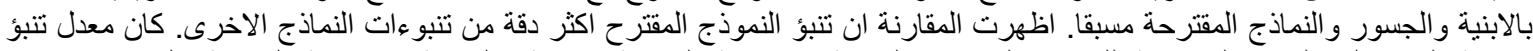

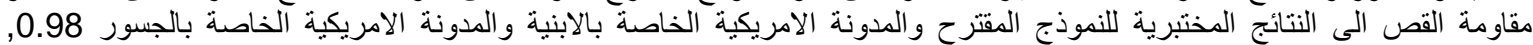
0.79, 0.75 على التو الي وكان الانحر اف المعياري 0.17, 0.28, 0.49 على التو الي.

الكلمات المفتاحية: الخرسانة المسلحة, العتبات العميقة, مقاومة القص, معامل كفاءة الخرسانة, نموذج الدعامة و الرباط.
} 